\title{
New Nickel Metal Complex towards Biomimetic Catecholase Enzyme Oxidation: Synthesis and Kinetics Studies
}

\author{
Mohamed M. Al-Sayed \\ Chemistry Department, Faculty of Science \& Arts Al-Mukhwah, Al-Baha University, Al-Baha, Saudi Arabia
}

Email address:

omarmoaz180@yahoo.com

To cite this article:

Mohamed M. Al-Sayed. New Nickel Metal Complex Towards Biomimetic Catecholase Enzyme Oxidation: Synthesis and Kinetics Studies. Biochemistry and Molecular Biology. Vol. 3, No. 1, 2018, pp. 1-5. doi: 10.11648/j.bmb.20180301.11

Received: August 24, 2017; Accepted: October 8, 2017; Published: January 12, 2018

\begin{abstract}
Pyrano[2,3-c]pyrazole ligand and their transition metal complex with nickel (Ni $\left.{ }^{\mathrm{II}} \mathrm{MPC}\right)$ were synthesized and characterization by elemental analyses, magnetic susceptibility, FT IR, UV-Vis, and mass spectroscopy. Complex have been investigated as functional models for catechol oxidase activity by using a catechol as a model substrate. According to the kinetic measurement results, the rate of catechol oxidation follows first order kinetics. Nickel complex has been used in homogenous oxidation of catechol in presence of a green oxidant $\mathrm{H}_{2} \mathrm{O}_{2}$. kinetic parameters were obtained $\mathrm{V}_{\max }=2.698 \times 10^{-3} \mathrm{MS}^{-1}, K_{m}=7.878 \mathrm{M}$, $k_{c a t}=4.496 \times 10^{-2} \mathrm{~S}^{-1}$ and $k_{\text {cat }} / K_{m}=0.5707 \mathrm{M}^{-1} \mathrm{~S}^{-1}$.
\end{abstract}

Keywords: Pyrano[2,3-c]Pyrazole, Nickel, Oxidation, Catecholase

\section{Introduction}

Metals have an esteemed place in medicinal chemistry. Transition metal complexes have been widely studied in the area of bio-inorganic and catalytic chemistry $[1,2]$ Metal complexes with active drugs as ligands is a research area of increasing interest for inorganic and medicinal chemistry and has concentrated much attention as an approach to new drug development $[3,4]$.

The oxidation of phenols compounds under moderate conditions is very important in the decay of aromatic compounds and in industrial catalysis for environmental ecology [5]

Latterly much works have been based on pyrazole ligands to form metal complex to mimic catecholase enzyme function [6-7] pyrazole ligand have identical structure of imidazole ring, the imidazole ring of amino acid remains is combined ligands at the energetic sites of metalloproteinase which guided to employ pyrazole to mimic the function of catecholase [8].

Pyrano[2,3-c]pyrazoles has been many applications in the field of pharmaceuticals [9] these compounds have biological activity and pharmacological [10] anticancer, [11, 12] antiinflammatory, [13].
Catecholase widespread in plant enzyme, to save plant from harm result by insects and pathogens by catalytic oxidation of catechol to $o$-quinones in the presence of oxygen air $[14,15]$ catecholase activity mimicking by biomaterials structural, metal complexes considered in recent years the most important in a study of their catalytic activity in oxidation reactions [16] in spite of the powerful site of catecholase enzyme consists of a hydroxo-bridged dicopper(II) center, it is fully certified that many monometallic complexes of $\mathrm{Mn}(\mathrm{II})$ [17], Ni(II) [18], copper(II) [19] and Fe(II) [20] are show catecholase activity.

To more recognize the effect of concentration and nature of substrate the reaction follow up Michaelis-Menten [21] to study the kinetic of enzymatic reaction to limitation the kinetic parameters.

\section{Experimental}

\subsection{Materials and Methods}

Aromatic aldehydes and its substituted derivatives, were 
purchased from Aldrich Chemical Co. malononitrile, 3methyl-1-phenyl-2- pyrazolin-5-one and triethylbenzylammonium chloride (TEBA) were purchased from Across Organics Co. (Belgium). Nickel chloride was obtained from Merck Co., Germany.

\subsection{Synthesis of (6-amino-4-(4-methoxyphenyl)-3-methyl- 1-phenyl-1,4-dihydropyrano[2,3-c]pyrazole-5- carbonitrile) (MPC)}

When aromatic aldehydes (1), malononitrile (2), 3-methyl1-phenyl-2- pyrazolin-5-one (3), and triethylamine were heated under reflux, the products (4) were obtained in good yields [22] The infrared spectrum of the (MPC) shows band at $3382 \mathrm{~cm}^{-1}$ with one at $3317 \mathrm{~cm}^{-1}$ assigned to $v \mathrm{NH}_{2}$. The ligand also shows strong bands at $2190 \mathrm{~cm}^{-1}, 1511 \mathrm{~cm}^{-1}$ assigned to $\vee \mathrm{C}=\mathrm{C}, v \mathrm{C} \equiv \mathrm{N}$. the mass spectroscopy $(\mathrm{m} / \mathrm{z}=$ 358.1) M. p. 173-1758C (Lit. [23] 170-1728C).

${ }^{1} \mathrm{H}$ NMR (DMSO-d6, d, ppm): $1.78\left(3 \mathrm{H}, \mathrm{s}, \mathrm{CH}_{3}\right), 3.74\left({ }^{3} \mathrm{H}\right.$, s, $\left.\mathrm{CH}_{3} \mathrm{O}\right), 4.63\left({ }^{1} \mathrm{H}, \mathrm{s}, \mathrm{C}_{4}-\mathrm{H}\right), 6.90\left({ }^{2} \mathrm{H}, \mathrm{d}, \mathrm{J} 1 / 48.4 \mathrm{~Hz}, \mathrm{ArH}\right)$, 7.16-7.17 ( $\left.{ }^{4} \mathrm{H}, \mathrm{m}, \mathrm{NH}_{2} \mathrm{ArH}\right), 7.30-7.34\left({ }^{1} \mathrm{H}, \mathrm{m}, \mathrm{ArH}\right), 7.47-$ $7.51\left({ }^{2} \mathrm{H}, \mathrm{m}, \mathrm{ArH}\right), 7.78\left({ }^{2} \mathrm{H}, \mathrm{d}, \mathrm{J} 1 / 48.8 \mathrm{~Hz}, \mathrm{ArH}\right)$.

Anal. Calcd. for $\mathrm{C}_{21} \mathrm{H}_{18} \mathrm{~N}_{4} \mathrm{O}_{2}$ : C 70.38, H 5.06, N 15.63; found C 70.54, H 4.89, N 15.40 [24]. ("Figure 1").

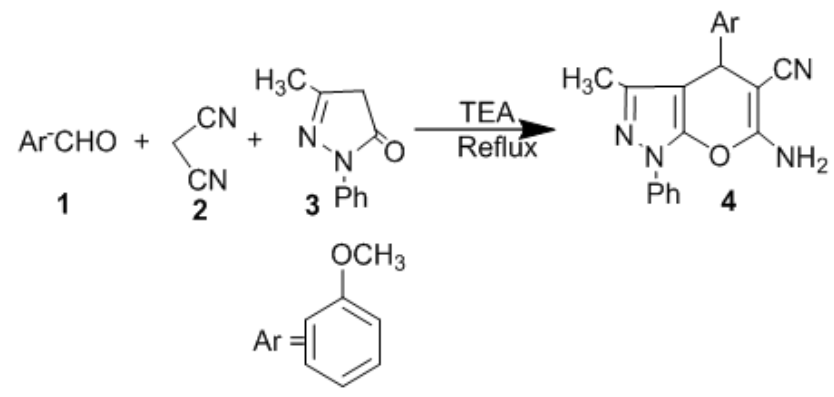

Figure 1. Synthesis of MPC ligand.

\subsection{Synthesis of [NiMPC] Complex}

Nickel (II) chloride (0.1 mole) was dissolved in $\sim 40 \mathrm{ml}$ absolute ethanol, then added to 0.1 mole of the prepared ligand (MPC) dissolved in $\sim 40 \mathrm{ml}$ absolute ethanol. The mixture was heated under reflux for two hrs. A bluish precipitate was formed that was filtered off and finally washed by hot ethanol several times.

\subsection{Catecholase Activity and Kinetic Measurements of Oxidation Activities}

The kinetics measurements of the reactions were studied spectroscopically the catalytic activity of the $\mathrm{Ni}^{\mathrm{II}} \mathrm{MPC}$ complex toward the homogenous oxidation of catechol in methanol solution at $25^{\circ} \mathrm{C}$ was determined by measuring the initial rate of catechol oxidation. The increase of the absorption at $390 \mathrm{~nm}$ [25] due to the oxidation product with time was obtained on a Varian Cary $3 \mathrm{E}$ spectrophotometer. A plot of the formation of the product with respect to time gives the initial rate. $60 \mu \mathrm{M}$ of the $\mathrm{Ni}^{\mathrm{II}} \mathrm{MPC}$ catalyst has been used in the oxidation of different concentrations of the substrate
$(5-150 \mu \mathrm{M})$ in presence of $100 \mu \mathrm{M} \mathrm{H}_{2} \mathrm{O}_{2}$ to study the effect of catechol concentration on the reaction. The rate laws were determined and rate constants obtained.

\subsection{Instrumentation}

Carbon, hydrogen and nitrogen contents were determined at the Micro analytical Unit, Cairo University, Egypt. IR spectra of the ligand and its solid complexes were measured in $\mathrm{KBr}$ on a Mattson 5000 FTIR spectrometer. The electronic spectra and kinetic measurements were performed using Varian Cary 4 Bio UV/VIS spectrophotometer. ${ }^{1} \mathrm{H}$ - NMR spectrum of the ligand was recorded on Joel-90Q Fourier Transform (200 MHz) spectrometers in $\left[\mathrm{D}_{6}\right]$ DMSO. The mass spectra of Thermal analysis measurements (TGA) were recorded on a Shimadzu thermo-gravimetric analyzer model TGA-50 H, using $20 \mathrm{mg}$ samples. The flow rate of nitrogen gas and heating rate were $20 \mathrm{~cm}^{3} \mathrm{~min}^{-1}$ and $10^{\circ} \mathrm{C} \mathrm{min}^{-1}$ respectively. The magnetic susceptibility measurement for the nickel (II) complex was determined by the Gouy balance using $\mathrm{Hg}\left[\mathrm{Co}(\mathrm{NCS})_{4}\right]$ as a calibrate at room temperature.

\section{Results and Discussion}

\subsection{FT-IR}

The pyrazolyl derivative was synthesized and characterized by ${ }^{1} \mathrm{H}$ NMR, IR, mas and elemental analysis [22].

By compering of FT-IR of ligand (MPC) and $\mathrm{Ni}^{\mathrm{II}} \mathrm{MPC}$ complex strong band appeared at $2195 \mathrm{~cm}^{-1}$ which is given to the $\mathrm{C} \equiv \mathrm{N}$ vibrations in ligand this band was vanish in the $\mathrm{Ni}$ (II) complex. Shifting in $\mathrm{vNH}_{2}$ bands to higher wavelength ( 3430 and $3320 \mathrm{~cm}^{-1}$ ) and this is supported the Ni(II) bind to MPC ligand through the nitrogen atom of $\mathrm{NH}_{2}$ and nitrogen atom of $\mathrm{CN}$. a new band at $475 \mathrm{~cm}^{-1}$ due to $\mathrm{vNi}-\mathrm{N}$ [26]. This also confirming structure by the presence of new band at 545 $\mathrm{cm}^{-1}$ to $v \mathrm{Ni}-\mathrm{O}[27]$.

\subsection{Electronic Spectral Data}

At room temperature these complexes show magnetic moment in the range $2.98 \mathrm{BM}$. These values are in tune with a high spin configuration and show the presence of an octahedral environment [28] around the $\mathrm{Ni}$ (II) ion in the complexes. Exhibit absorption bands in the range $260 \mathrm{~nm}$ and $480 \mathrm{~nm}$. An examination of these bands indicates that the complexes have an octahedral geometry. The ground state of $\mathrm{Ni}$ (II) in an octahedral coordination is ${ }^{3} \mathrm{~A}_{2 g}$. Thus, these bands may be assigned to the three spin allowed transitions [29]. ${ }^{3} \mathrm{~A}_{2 g}(\mathrm{~F}) \rightarrow{ }^{3} \mathrm{~T}_{2 g}(\mathrm{~F})-(v 1),{ }^{3} \mathrm{~A}_{2 g}(\mathrm{~F}) \rightarrow{ }^{3} \mathrm{~T}_{1 g}(\mathrm{~F})-(v 2)$, ${ }^{3} \mathrm{~A}_{2 g}(\mathrm{~F}) \rightarrow{ }^{3} \mathrm{~T}_{1 g}(\mathrm{P})-(v 3)$, Respectively these support an octahedral geometry [30].

\subsection{Mass Spectrum}

Nickel complex "Figure 2" shows a molecular ion peak at $\mathrm{m} / \mathrm{z}=537$ corresponding to the nickel complex moiety 
$\left(\mathrm{C}_{21} \mathrm{H}_{22} \mathrm{Cl}_{2} \mathrm{NiN}_{4} \mathrm{O}_{5}\right)$. The base peak was found in the spectrum at $\mathrm{m} / \mathrm{z}=54(100 \%)$ mass fragmentation pattern of metal complex shows in "Figure 3"

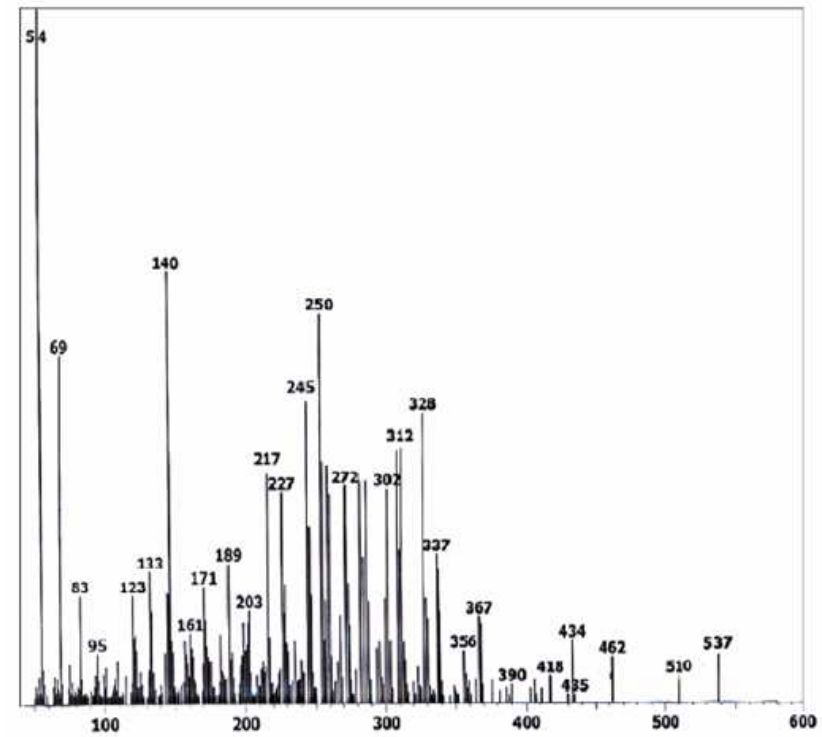

Figure 2. Mass spectrum of $\left[\mathrm{Ni}(\mathrm{MPC})(\mathrm{OH})_{2} \mathrm{Cl}_{2}\right] \mathrm{H}_{2} \mathrm{O}$.
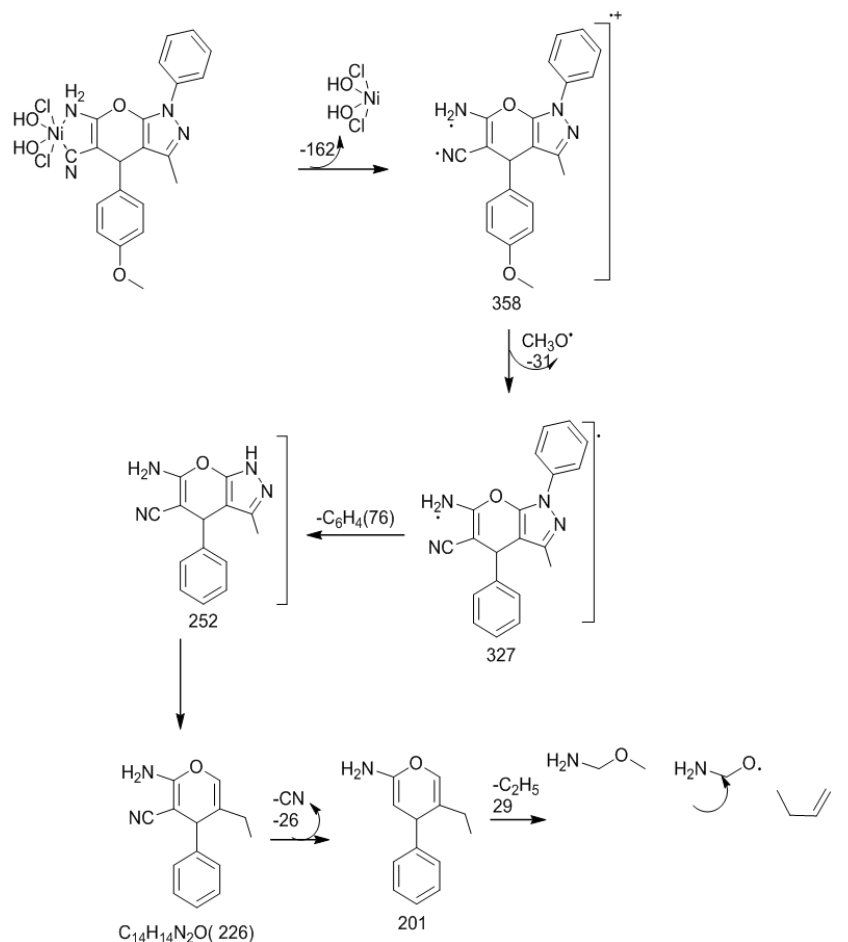

Figure 3. Mass fragmentation pattern of metal complex.

\subsection{Elemental Analysis}

$\mathrm{Ni}^{\mathrm{II}} \mathrm{MPC}$ complex shown $\% \mathrm{C}$ (cal; 46.71, foud; 46.31)\% H (cal; 4.11, Foud; 4.02)\% N (cal; 10.38 foud; 10.24$) \% \mathrm{Ni}$ (cal; 10.87 foud; 10.78 ).

The elemental analysis addition to IR, mass spectroscopy, magnetic moment and electronic spectral all this give the structure (1) of $\mathrm{Ni}^{\mathrm{II}} \mathrm{MPC}$.

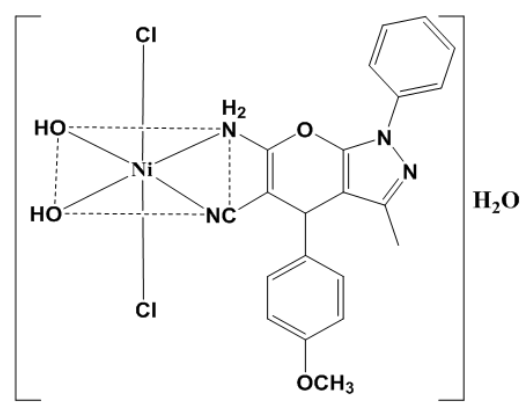

Structure (1) chemical structure of $\mathrm{Ni}^{\mathrm{II}} \mathrm{MPC}$

\subsection{Catalytic Activity and Kinetic Study of Catecholase}

\subsubsection{Effect of Concentration of Catalyst}

In order to investigate the effect of the concentration of catalyst on the oxidation of catechol with different concentrations of the nickel complex $\mathrm{Ni}^{\mathrm{II}} \mathrm{MPC}$ have been used in the oxidation of catechol. The initial rate $V_{i}=9 \times 10^{-4}$ was found to be linear till $60 \mu \mathrm{M}$ and then reach a saturation stage "Figure 4"

\subsubsection{Effect of Substrate}

Since catechol is instantaneously oxidized by activated $\mathrm{H}_{2} \mathrm{O}_{2}$, the rate-determining step in this case is the activation of $\mathrm{H}_{2} \mathrm{O}_{2}$. Thus, catechol here serves as a "redox indicator". In order to establish the rate law for the homogeneous catechol oxidation by nickel complex, the rate is further determined at various concentrations of catechol at $25^{\circ} \mathrm{C}$ in ethanol solution. The rate of catechol oxidation using $60 \mu \mathrm{M}$ complex $\mathrm{Ni}^{\mathrm{II}} \mathrm{MPC}$ against different concentrations of catechol is measured and found to be hyperbolic with respect to [catechol], suggesting the possibility of a pre-equilibrium kinetics. This kinetics can be described as the binding of the substrate catechol (S) to the metal center $\mathrm{Ni}^{\mathrm{II}} \mathrm{MPC}$ to form the intermediate Pyrano[2,3-c]pyrazole nickel complex, followed by the conversion of the bound substrate into the product. The first order rate constant $\mathrm{k}_{\mathrm{cat}}$ and dissociation constant $\mathrm{K}_{\mathrm{m}}$ are found. The small value of the $\mathrm{K}_{\mathrm{m}}$ indicates a very good binding between the nickel complex and substrate catechol.

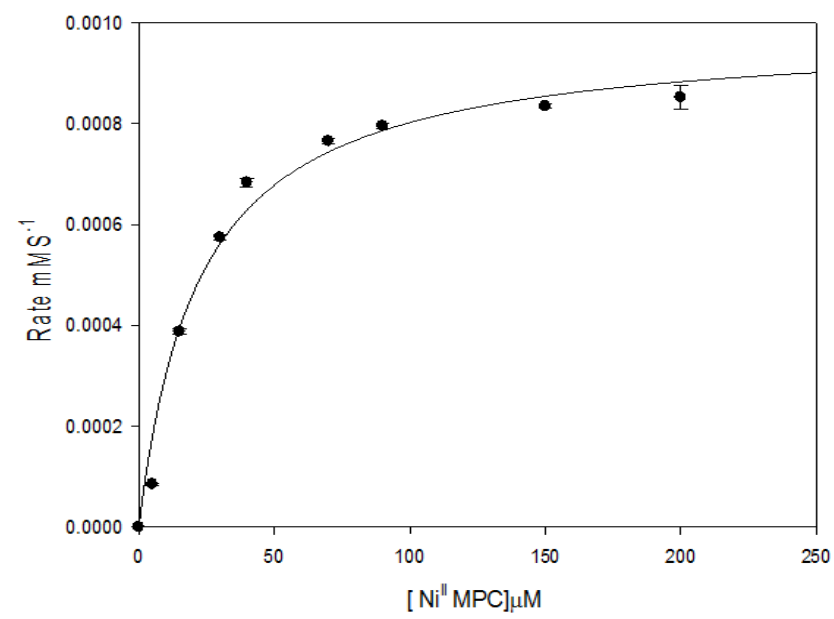

Figure 4. Oxidation of $1 \mathrm{mM}$ of catechol using different concentrations of the catalyst $N i^{I I} \mathrm{MPC}$ at $25^{\circ} \mathrm{C}$. 
The catecholase activity of the complexes was studied using catechol as substrate in ethanol at temperature $25^{\circ} \mathrm{C}$ is observed in catechol was determined by measuring The increase of the absorption at $390 \mathrm{~nm}$ with time due to the oxidation product with time was obtained "Figure 4" on a Varian Cary 3E spectrophotometer in the presence of $\mathrm{H}_{2} \mathrm{O}_{2}$ solution as an oxygen source. By applying traditional the Michaelis-Menten approach "Figure 5", values of the kinetic parameters $\mathrm{V}_{\text {max }}, \mathrm{K}_{\mathrm{m}}, \mathrm{k}_{\mathrm{cat}}$ and $\mathrm{k}_{\text {cat }} / \mathrm{K}_{\mathrm{m}}$ were obtained from the corresponding plot of $\mathrm{Vi}$ versus [S] (different concentration catechol) in "Figure 6" $\mathrm{V}_{\max }=2.698 \times 10^{-3}, K_{m}=7.878 \mathrm{M}, k_{\text {cat }}=$ $4.496 \times 10^{-2} \mathrm{~S}^{-1}$. The reaction in concentration of catalyst $\mathrm{Ni}^{\mathrm{iI}} \mathrm{MPC}$ complex $60 \mu \mathrm{M}$ and in the presence of saturation amount of $\mathrm{H}_{2} \mathrm{O}_{2}(200 \mu \mathrm{M})$. produces important catalytic efficiency $k_{\text {cat }} / K_{m}=0.5707 \mathrm{M}^{-1} \mathrm{~S}^{-1}$ as second order rate constant.

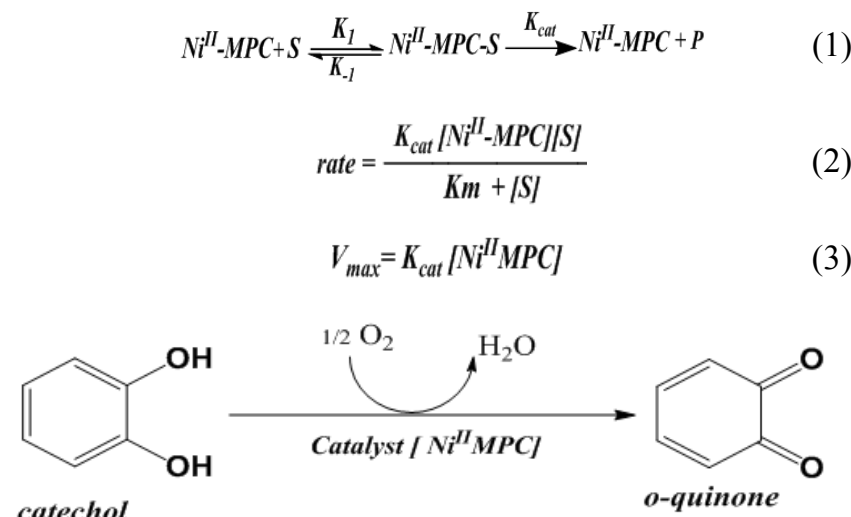

Figure 5. Oxidation of catechol to o-quinone.

\subsubsection{Effect of Concentration of Hydrogen Peroxide}

The rate of oxidation of catechol at various Concentrations of hydrogen peroxide using $60 \mu \mathrm{M}$ of the catalyst catechol complex shows saturation pattern at $200 \mu \mathrm{M}$ "Figure 7 ". This saturation behavior indicates that the hydrogen peroxide binds to the nickel complex or nikel complex banded to the substrate catechol.

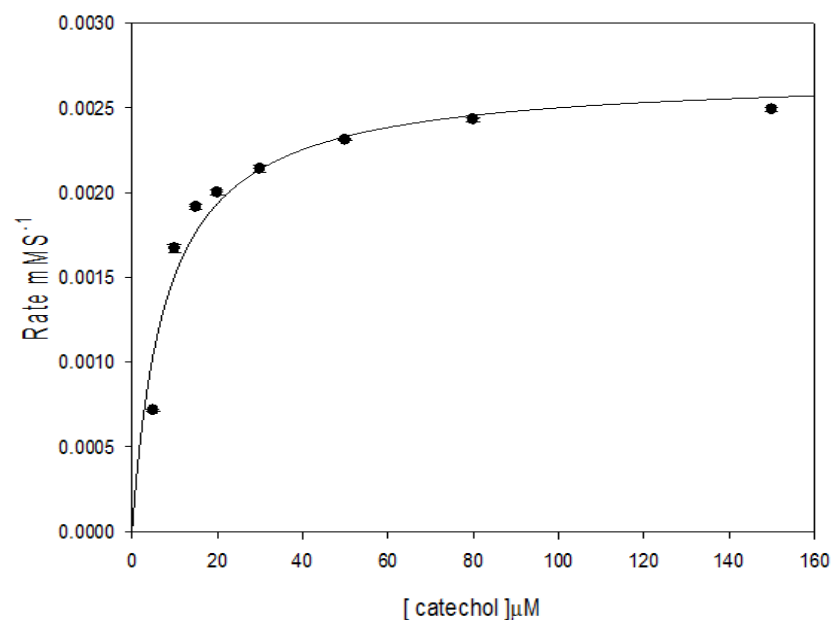

Figure 6. Plot of initial rate $\left(m M S^{-1}\right)$ VS [Substrate] $\mu M$ of catechol in presence of catalyst complex $N i^{I I} M P C 60 \mu M$ at $25^{\circ} \mathrm{C}$.

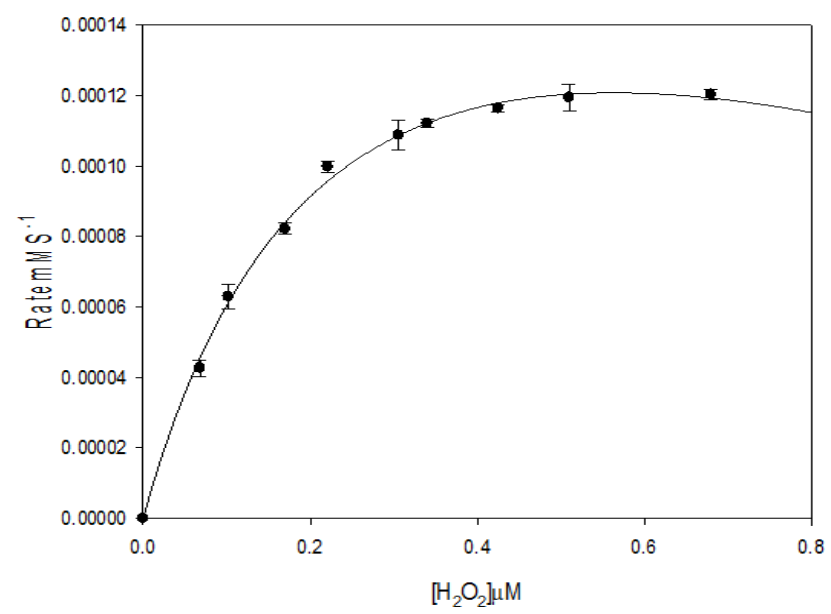

Figure 7. Oxidation of $1.0 \mathrm{mM}$ catechol using $60 \mu \mathrm{M} \mathrm{Ni} \mathrm{I}^{\text {II }} \mathrm{MPC}$ with different concentrations of $\mathrm{H}_{2} \mathrm{O}_{2}$ at $25^{\circ} \mathrm{C}$.

\section{Conclusion}

In this studies a new complex of Nickel was synthesized with pyrano[2,3-c]pyrazoles This complex was fully characterized by different tools (FT-IRI, Electronic spectral data, magnetic moment, Mass spectrum, Elemental analysis) The Ni(II) bind to MPC ligand through the nitrogen atom of $\mathrm{NH}_{2}$ and nitrogen atom of $\mathrm{CN}$. The geometry around the Nickel ion is found to be octahedral geometry. In this study The $\left[\mathrm{Ni}^{\mathrm{II}} \mathrm{MPC}\right]$ complex has been used as a catalyst in the oxidation of catechol in presence of $\mathrm{H}_{2} \mathrm{O}_{2}$ as a green oxidant and this reaction biomimetic enzyme reaction and study the Effect of concentration of catalyst and Calculates The initial rate $V_{i .}$, study the effect of substrate (catechol) and Calculates the kinetic parameters $\mathrm{V}_{\text {max }}, \mathrm{K}_{\mathrm{m}}, \mathrm{k}_{\mathrm{cat}}$ and $\mathrm{k}_{\mathrm{cat}} / \mathrm{K}_{\mathrm{m}}$. in the end study Effect of concentration of hydrogen peroxide in oxidation of catechol.

\section{References}

[1] E. V. Akimova, D. H. Busch, P. K. Kahol, N. Pinto, N. W. Alcock, H. J. Clase, Inorg. Chem. 36 (1997) 510.

[2] H. Okawa, H. Sakiyama, Pure Appl. Chem. 67 (1995) 273.

[3] R. Cini, Inorg Chem. 22 (2000)151.

[4] D. Kovala, J Inorg Biochem 79 (2000)153.

[5] J. Haggin, Chem. Eng. News 71 (1993) 23.

[6] N. Boussaleh, R. Touzani, I. Bouabdallah, S. Ghalem, S. El Kadiri, Int. J. Acad. Res. 2 (2009) 137.

[7] A. Djedouani, F. Abrigach, M. Khoutoul, A. Mohamadou, A. Bendaas, A. Oussaid, R. Touzani, Orient. J. Chem. 31 (1) (2015) 97.

[8] A. Mouadili, A. El Ouafi, A. Attayibat, S. Radi, R. Touzani, J. Mater. Environ. Sci. 6 (2015) 2166.

[9] S. R. Mandha, S. Siliveri, M. Alla, V. R. Bommena, M. R. Bommineni, S. Balasubramanian, Bioorganic and Medicinal Chemistry Letters 22 (2012) 5272. 
[10] E. C. Witte, P. Neubert, A. Roesoh,. Chem. Abstr. 104 (1986) $224915 f$.

[11] J. L. Wang, D. Liu, Z. J. Zheng, S. Shan, X. Han, S. M. Srinivasula, C. M. Croce, E. S. Alnemri, Z. Huang, Proc. Natl. Acad. Sci. U.S.A. 97 (2009) 7124.

[12] M. E. A. Zaki, E. M. Morsy, M Abdul, Heterocycl. Commun. 10 (2004) 97.

[13] (a) M. E. A. Zaki, H. A. Saliman, O. A. Hickal, A. E. Rashad, Natureforsch, C: Biosci. 61 (2006)1. (b) C. K. Sheng, J. H. Li, N. J. Hideo, Med. Chem. 27 (1984) 539.

[14] SK. Mal, M. Mitra, H. Yadav, CS. Purohit, AR. Choudhury, R. Ghosh, Polyhedron. 111 (2016) 118.

[15] N. Beyazit, D. Çakmak, C. Demetgül, Tetrahedron 73 (2017) 2774.

[16] KC. Gupta, AK. Sutar, Coord Chem Rev. 252 (2008) 1420.

[17] M. Mitra, AK. Maji, BK. Ghosh, et al. Polyhedron. 61 (2013) 15.

[18] AK. Ghosh, M. Mitra, A. Fathima, et al. Polyhedron. 107 (2016) 1.

[19] S. Anbu, A. Paul, APC. Ribeiro, Inorg Chim Acta. 450 (2016) 426.

[20] T. Megyes, Z. May, G. Schubert, T. Grosz, LI. Simandi, T. Radnai, Inorg Chim Acta. 359 (2006) 2329.
[21] L. Michaelis, M. L. Menten, Biochem. Z 49 (1913) 333.

[22] S. R. Mandha, S. Siliveri, M. Alla, V. R. Bommena, M. R. Bommineni, S. Balasubramanian, Bioorganic and Medicinal Chemistry Letters 22 (2012) 5272.

[23] J. F Zhou, S. J. Tu, Y. Gao, M. Ji, J. Org. Chem. 21 (2001) 742 .

[24] S. R. Mandha, S. Siliveri, M. Alla, V. R. Bommena, M. R. Bommineni, S. Balasubramanian, Bioorganic and Medicinal Chemistry Letters 22 (2012) 5272.

[25] Z. Bouanane, M Bounekhel, M. Elkolli, F. A. brigach, M. Khoutoul, R. Bouyala, R. Touzani, A. Hellal, Journal of Molecular Structure 1139 (2017) 238.

[26] S. J. Zhuang, Q. X. Wang, J. Chem. Res. (2004)821.

[27] J. R. Ferraro, Plenum, New York (1971).

[28] A. A. El-Asmy, Y. M. Shaibi, I. M. Shedaiwa, M. A. Khattab, Inorg. Met. Org. Chem. 18 (1988)331.

[29] A. B. P. Lever, "Inorganic Electronic Spectroscopy", Elsevier, Amsterdam, (1986).

[30] A. A. El-Asmy, M. Mounir, Transition Met. Chem. 13 (1988)143. 